\title{
Nueva especie del género Urobatis (Myliobatiformes: Urotrygonidae) del Pacífico oriental tropical
}

\author{
Luis Fernando Del Moral-Flores ${ }^{1,2}$, Arturo Angulo 3 , Myrna I. López ${ }^{3,4}$ \\ \& William A. Bussing $\dagger^{3,4}$ \\ 1. Posgrado en Ciencias Biológicas, Universidad Nacional Autónoma de México; Av. Ciudad Universitaria 3000, C. P. \\ 04360, Coyoacán, Distrito Federal, México; delmoralfer@gmail.com \\ 2. Laboratorio de Zoología, Facultad de Estudios Superiores Iztacala, Universidad Nacional Autónoma de México. Av. \\ de los Barrios No. 1, Los Reyes Iztacala, 54090 Tlalnepantla, Estado de México, México. \\ 3. Museo de Zoología, Escuela de Biología, Universidad de Costa Rica, 11501-2060, San Pedro de Montes de Oca, San \\ José, Costa Rica; arturo.angulosibaja@ucr.ac.cr, myrna.lopez@ucr.ac.cr, william.bussing@ucr.ac.cr \\ 4. Centro de Investigación en Ciencias del Mar y Limnología, Universidad de Costa Rica, 11501-2060, San Pedro de \\ Montes de Oca, San José, Costa Rica.
}

\section{Recibido 08-IX-2014. ～Corregido 12-I-2015. ～Aceptado 03-II-2015.}

\begin{abstract}
A new species of Urobatis (Myliobatiformes: Urotrygonidae) from the tropical Eastern Pacific. A new species of round stingray, Urobatis pardalis sp. nov., is described from material collected in the Pacific coast of Costa Rica. This new species differs from its congeners by the color pattern of the dorsal surface and by several proportional measurements. A key to all species of the genus is provided. Rev. Biol. Trop. 63 (2): 501-514. Epub 2015 June 01.
\end{abstract}

Key words: new species, Urobatis pardalis sp. nov., round stingray, Costa Rica, Central America.

La familia Urotrygonidae está representada actualmente por dos géneros (Urobatis Garman, 1913; Urotrygon Gill, 1863) y 19 especies válidas (in parte, Compagno, 2005; Eschmeyer, 2014; Froese, \& Pauly, 2014; Nelson, 2006); distribuidas en el Pacífico oriental y en el Atlántico occidental (Compagno, 2005; Nelson, 2006). En 1996 McEachran, Dunn y Miyake establecen esta familia y la distinguen de Urolophidae, la cual incluía formalmente a ambos géneros (e.g., Bigelow, \& Shroeder, 1953; Castro-Aguirre, \& Espinosa-Pérez, 1996; Compagno, 1999; Nelson, 1994). Dentro de esta última se reconocen actualmente los géneros Trygonoptera Müller y Henle (1841) y Urolophus Müller y Henle, 1937, con seis y 22 especies válidas respectivamente (Pollerspöck, 2014), mismas que restringen su distribución al Indopacífico occidental (Last, \& Compagno,
1999; Last, \& Stevens, 1994; Yearsley, Last, \& Gomon, 2008).

El género Urobatis (sensu McEachran et al., 1996) fue considerado un sinónimo de Urolophus (Cappetta, 1987; Nelson et al., 2004); no obstante puede distinguirse de éste por la forma del disco, específicamente su relación ancho/largo, por la longitud de la cola y por la longitud, altura y forma de la aleta caudal, entre otros caracteres (McEachran et al., 1996; Nelson, 2006; Robertson, \& Allen, 2008). En el Atlántico occidental el género Urobatis está representado por una única especie, $U$. jamaicensis (Cuvier, 1816), la cual se distribuye desde el Cabo Lookout en Carolina del Norte, EEUU, hasta las costas de Venezuela, incluyendo las Antillas y Bahamas (Aguilera, 1998; Böhlke, \& Chaplin, 1968; CervigónMarcos, \& Ramírez-Nahim, 2012; McEachran, 
\& Fechhelm, 1998). En el Pacífico oriental este género está representado por cinco especies: $U$. concentricus Osburn y Nichols (1916), distribuida desde el Golfo de California hasta el sur de México (Beebe, \& Tee-Van, 1941; Márquez-Espinosa, 2012); U. halleri (Cooper, 1863), distribuida desde la costa de California, EEUU, hasta la costa sur de México (MárquezEspinosa, 2012; Miller, \& Lea, 1972); U. maculatus Garman (1913), endémica del Golfo de California (Castro-Aguirre, \& EspinosaPérez, 1996); U. marmoratus (Philippi, 1892) restringida a la costa central de Chile (De Buen, 1959); y U. tumbesensis (Chirichigno, \& McEachran, 1979), distribuida desde Colombia hasta Perú (Chirichigno, 1974; Chirichigno, \& McEachran, 1979; Mejía-Falla, \& BolañosCubillo, 2011; Mejía-Falla, \& Navia, 2009).

La especie Urolophus nebulosus, descrita por Garman (1885) a partir de un ejemplar recolectado en Colima, México, ha sido puesto bajo sinonimia de Urobatis halleri por CastroAguirre \& Espinosa-Pérez (1996), no obstante, de acuerdo con los caracteres diagnósticos de la descripción original, esta especie debería ser asignada al género Urotrygon (sensu McEachran et al., 1996), por lo cual es necesaria una revisión de su estatus. Por otra parte, la especie Urolophus umbrifer Jordan \& Starks, 1895 (Jordan, 1895) descrita a partir de ejemplares provenientes de Mazatlán, Sinaloa, México, corresponde a un sinónimo válido de $U$. halleri (Castro-Aguirre, \& Espinosa Pérez, 1996). Al revisar parte de esta problemática y al examinar ejemplares de Urobatis a lo largo de su distribución en ambas costas del continente Americano, se ha corroborado la existencia de una séptima especie hasta el momento no descrita. Esta nueva especie se ha confundido y asignado bajo el nombre de $U$. halleri por presentar un patrón de coloración reticular; su distribución se limita al Pacífico de Costa Rica, Panamá y Colombia (v.gr., Allen, \& Robertson, 1998; Bussing, \& López, 2005, 2011; Mejía-Falla, \& Bolaños-Cubillos, 2011). En la presente contribución esta nueva entidad se describe formalmente. Se incluye además una clave para la determinación taxonómica de las especies del género.

\section{MATERIALES Y MÉTODOS}

Se examinó material de las siguientes colecciones de referencia: Colección Nacional de Peces, Instituto de Biología de la Universidad Nacional Autónoma de México (CNPEIBUNAM) y Museo de Zoología, Escuela de Biología, Universidad de Costa Rica (UCR). La evaluación taxonómica del mismo se realizó contrastando las descripciones originales de las especies válidas, sinónimos y enmiendas taxonómicas propias del género Urobatis (Chirichigno, \& McEachran, 1979; Cooper, 1863; Cuvier, 1816; Garman, 1913; Jordan, \& Starks, 1895; Osburn, \& Nichols, 1916; Philippi, 1892). A cada espécimen se le tomaron un de total de 46 medidas (Cuadro 1), de acuerdo con el protocolo establecido por Bigelow \& Schoereder (1953), con algunas modificaciones de Chirichigno \& McEachran (1979), López \& Bussing (1998) y Miyake \& McEachran (1988). Las medidas se expresan como porcentaje de la Longitud Total (LT). Información comparativa (morfológica, morfométrica y merística) fue obtenida de las siguientes fuentes: Chirichigno \& McEachran (1979), McEachran (1995), Lamilla \& Sáez (2003), McEachran \& de Carvalho (2003), Lamilla \& Bustamante (2005), Robertson \& Allen (2008), Mejía-Falla \& Navia (2009), y Mejía-Falla \& Bolaños-Cubillo (2011).

\section{RESULTADOS}

\section{Urobatis pardalis sp. nov.}

(Figs. 1-7, Cuadro 1)

Urobatis halleri (no Cooper, 1863): Allen, \& Robertson, 1994, en parte: 35 descripción; McEachran, 1995, en parte: 787 clave, 789 descripción; Allen, \& Robertson, 1998, en parte: 34 descripción; Bussing \& López, 2009: 441 lista; Bussing \& López, 2011: 34 lista, 
descripción; Mejía-Falla \& Bolaños-Cubillo, 2011: 244-245 descripción.

Holotipo: UCR 2289-01, hembra adulta (462 mm LT), recolectada en Playa Escondida, lado norte de la Bahía, Provincia de Puntarenas, Costa Rica ( $9^{\circ} 40^{\prime} 0.0012^{\prime \prime} \mathrm{N}-84^{\circ} 40^{\prime}$ 24.6" O), el 12 de Junio de 1992, por William A. Bussing, mediante arpón, a una profundidad de $11-14 \mathrm{~m}$.

\section{CUADRO 1}

Datos morfométricos del holotipo de Urobatis pardalis sp. nov. (UCR 2289-1), con los intervalos de los paratipos ( $\mathrm{n}=21)$ (adultos y embriones). Valores expresados como porcentaje de LT

\begin{tabular}{|c|c|c|c|c|c|}
\hline \multirow{3}{*}{ Medidas } & \multirow{3}{*}{ Holotipo } & \multicolumn{4}{|c|}{ Paratipos } \\
\hline & & \multicolumn{2}{|c|}{ Adultos $(n=4)$} & \multicolumn{2}{|c|}{ Embriones $(\mathrm{n}=17)$} \\
\hline & & Mín. & Máx. & Mín. & Máx. \\
\hline Longitud total (mm) & 462 & 304 & 377 & 110 & 139 \\
\hline Ancho del disco & 64.7 & 62.0 & 65.5 & 50.0 & 54.9 \\
\hline Longitud del disco & 64.3 & 64.1 & 65.8 & 51.9 & 56.7 \\
\hline Longitud prenasal & 9.6 & 8.6 & 8.7 & 6.5 & 9.4 \\
\hline Longitud preoral & 13.0 & 11.5 & 12.6 & 9.6 & 12.6 \\
\hline Longitud preorbital & 15.1 & 11.8 & 13.0 & 9.3 & 14.3 \\
\hline Longitud preespiracular & 16.1 & 14.1 & 14.6 & 12.0 & 16.5 \\
\hline Longitud precaudal & 82.9 & 78.5 & 86.0 & 82.5 & 86.1 \\
\hline Distancia hocico 1r abertura branquial & 21.9 & 19.5 & 20.5 & 19.1 & 22.2 \\
\hline Distancia hocico $3 r$ abertura branquial & 26.6 & 24.0 & 24.7 & 23.4 & 26.8 \\
\hline Distancia hocico 5 ta abertura branquial & 30.4 & 28.8 & 30.2 & 27.1 & 31.1 \\
\hline Longitud cefálica & 57.4 & 54.3 & 57.6 & 46.6 & 51.3 \\
\hline Longitud prepélvica & 51.5 & 50.5 & 52.4 & 44.2 & 47.6 \\
\hline Distancia hocico al inicio del ano & 53.2 & 51.1 & 53.0 & 46.2 & 50.7 \\
\hline Ancho entre axilas pectorales & 14.7 & 13.2 & 15.5 & 9.3 & 13.6 \\
\hline Distancia axila pélvica al inicio de la caudal & 26.0 & 22.1 & 23.0 & 20.8 & 25.8 \\
\hline Distancia origen pélvica al inicio caudal & 30.2 & 30.7 & 33.9 & 27.4 & 32.4 \\
\hline Largo narina & 2.2 & 2.0 & 2.6 & 1.6 & 2.8 \\
\hline Ancho cortina nasal & 7.3 & 6.9 & 7.9 & 5.8 & 6.8 \\
\hline Largo cortina nasal & 3.4 & 2.6 & 3.4 & $2.2)$ & 3.5 \\
\hline Diámetro orbital & 3.1 & 3.1 & 3.6 & 3.6 & 5.8 \\
\hline Espacio interorbital & 7.7 & 6.9 & 8.3 & 6.0 & 9.4 \\
\hline Espacio interorbital máximo & 12.0 & 11.3 & 13.8 & 11.2 & 16.0 \\
\hline Ancho internasal externo & 8.1 & 8.0 & 9.9 & 5.8 & 8.9 \\
\hline Longitud del espiráculo & 3.9 & 4.7 & 5.0 & 5.9 & 9.0 \\
\hline Ancho del espiráculo & 2.9 & 1.9 & 2.7 & 4.0 & 7.8 \\
\hline Distancia intraespicular & 9.2 & 9.3 & 9.7 & 8.6 & 11.2 \\
\hline Ancho boca, entre quijada & 7.0 & 5.7 & 7.1 & 5.8 & 6.9 \\
\hline Ancho boca, entre comisura de pliegues labiales & 8.4 & 8.1 & 9.1 & 7.1 & 10.8 \\
\hline Ancho 1r abertura branquial & 1.5 & 1.5 & 2.1 & 1.5 & 2.8 \\
\hline Ancho $3 \mathrm{r}$ abertura braquial & 2.3 & 2.1 & 2.3 & 1.4 & 2.4 \\
\hline Ancho 5ta abertura branquial & 1.1 & 1.2 & 1.7 & 1.1 & 1.9 \\
\hline Distancia entre las 1 ras aberturas branquiales & 15.0 & 14.4 & 15.7 & 12.4 & 15.4 \\
\hline Distancia entre las 3ras aberturas branquiales & 13.3 & 11.7 & 13.9 & 11.5 & 14.3 \\
\hline Distancia entre las 5 tas aberturas branquiales & 9.7 & 9.9 & 11.1 & 8.4 & 10.6 \\
\hline Longitud cloaca & 4.1 & 3.7 & 4.7 & 2.9 & 4.7 \\
\hline Altura base pedúnculo caudal, axila pélvicas & 4.7 & 4.3 & 4.9 & 2.8 & 5.4 \\
\hline Ancho base pedúnculo caudal, axila pélvicas & 6.4 & 5.9 & 7.0 & 3.6 & 7.7 \\
\hline Margen anterior pélvica (derecha) & 13.1 & 11.2 & 13.3 & 8.8 & 12.3 \\
\hline Base pélvica (derecha) & 12.3 & 10.6 & 12.6 & 7.7 & 10.8 \\
\hline Margen interno pélvica (derecha) & 4.0 & 4.4 & 5.4 & 1.8 & 5.3 \\
\hline Margen posterior pélvica (derecha) & 14.1 & 12.1 & 13.4 & 7.5 & 11.4 \\
\hline Margen dorsal caudal & 8.9 & 7.5 & 8.5 & 12.7 & 17.6 \\
\hline Margen ventral caudal & 14.5 & 14.0 & 15.9 & 21.1 & 25.8 \\
\hline Margen posterior caudal & 4.1 & 4.0 & 4.4 & 4.7 & 6.8 \\
\hline Distancia cloaca extremo caudal & 45.5 & 46.2 & 48.0 & 46.7 & 51.4 \\
\hline
\end{tabular}


Paratipos: 21 especímenes. UCR 035716, 1 espécimen, hembra ( $377 \mathrm{~mm} \mathrm{LT),} \mathrm{reco-}$ lectada en Isla San José, Golfo de Papagayo, Provincia de Guanacaste, Costa Rica (10 ${ }^{\circ} 51^{\text {' }}$ 50.0004" N - 85 54'59.9898" O), el 14 de septiembre de 1969 , por R.T. Nishimoto y C. Stone, a una profundidad de $0.6-2.1 \mathrm{~m}$; UCR 0618-05, 1 espécimen, hembra (313mm LT), recolectada frente a Bahía Jobo, La Cruz, Provincia de Guanacaste, Costa Rica (11 ${ }^{\circ}$ ' 39.9984" N - 85 45'31.4742" O), el 15 de febrero de 1972, por William A. Bussing, a una profundidad de 5-11m; UCR 2336-14, 2 especímenes, machos (304-315mm LT), recolectados frente a Bahía Pavones, Golfito, Provincia de Puntarenas, Costa Rica ( $8^{\circ} 25^{\prime}$ 5.9988" N $83^{\circ} 13^{\prime}$ 5.9046" O), el 11 de diciembre de 1993, por Myrna I. López y William A. Bussing, a una profundidad de 53m; UCR 2503-01, 17 especímenes nonatos (110-139mm LT), recolectados en Playas del Coco, Carrillo, Provincia de Guanacaste, Costa Rica (10³3' 19.998" N - 85 42' 9.8496" O), el 23 de febrero de 1996, por Helena Molina.
Diagnosis: El holotipo (Fig. 1) y dos paratipos son hembras maduras; dos paratipos son machos que acaban de alcanzar la madurez, con el mixopterigio desarrollado y ligeramente calcificado; 17 paratipos están en estado nonatos (Fig. 2) y por esta condición no se utilizaron en la diagnosis ni en la descripción de la especie (ver apartado). Disco circular, la longitud del ancho y largo son similares; ancho del disco 62.0-65.5\% de LT; longitud del disco $64.1-65.8 \%$ de LT; longitud cefálica 54.3$57.6 \%$ de LT; distancia prepélvica 50.5-52.4\% de LT; distancia del hocico al ano 51.1-53.2\% de LT; longitud precaudal $78.5-86.0 \%$ de LT; longitud preespiracular $14.1-16.1 \%$ de LT; distancia entre la axila de las aletas pélvicas y el inicio de la caudal $22.1-26.0 \%$ de LT; ancho entre las axilas de las pectorales 13.2-15.5\% de LT; longitud del margen ventral y dorsal de la aleta caudal $14.0-15.9 \%$ y $7.5-8.9 \%$ de LT, respectivamente; 27 a 33 hileras de dientes en la mandíbula superior; dentículos o tubérculos dorsales ausentes; dorso del disco con un fondo de color pardo con tonos anaranjados
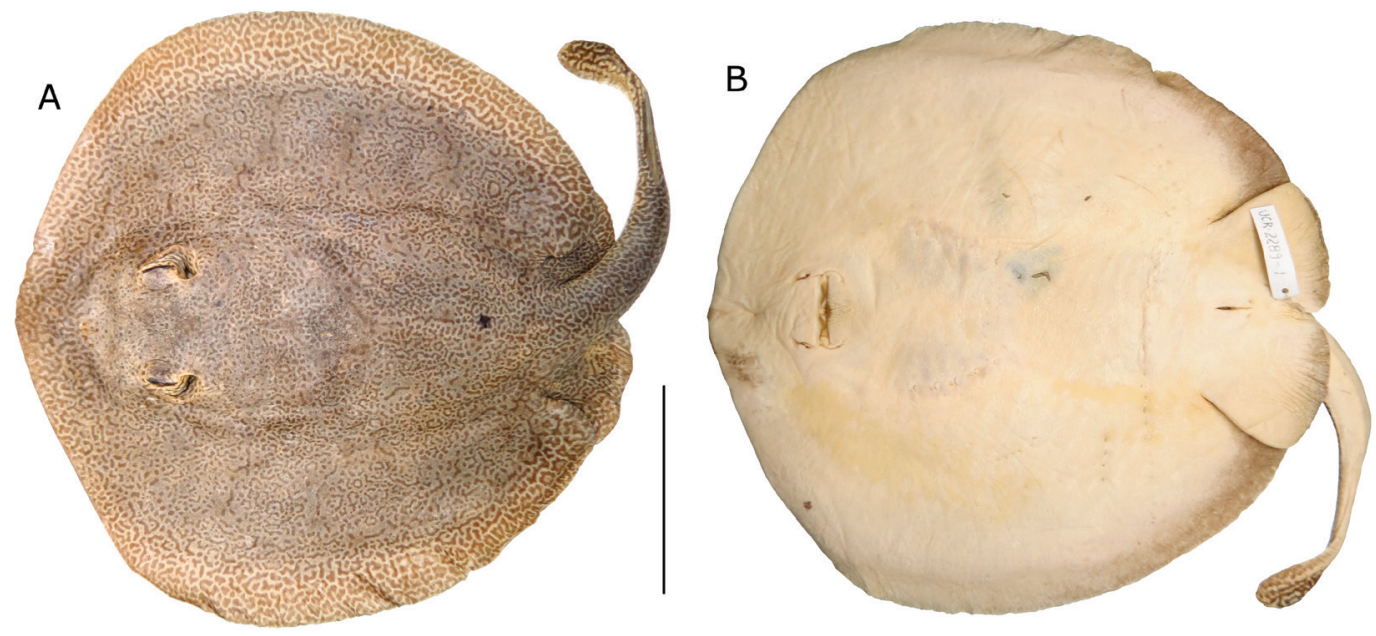

Fig. 1. Holotipo de Urobatis pardalis sp. nov. (UCR 2289-1, hembra madura, 462mm LT). A. Vista dorsal. B. Vista ventral. Barra de escala: $100 \mathrm{~mm}$.

Fig. 1. Holotype of Urobatis pardalis sp. nov. (UCR 2289-1, mature female, 462mm TL). A. Dorsal view. B. Ventral view. Scale bar: $100 \mathrm{~mm}$. 


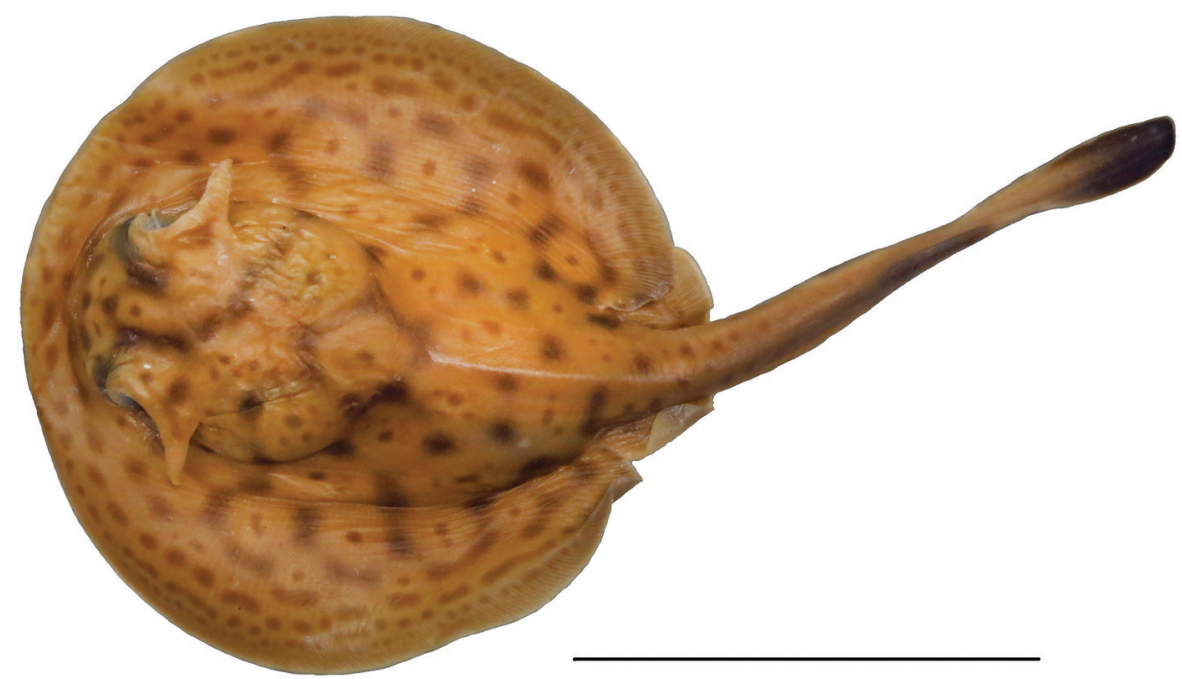

Fig. 2. Urobatis pardalis nov. sp., UCR 2503-1, paratipo, estado embrionario, Costa Rica. Barra de escala: 50mm. Fig. 2. Urobatis pardalis sp. nov., UCR 2503-1, Paratype embryo, Costa Rica, Scale bar: 50mm.

y vermiculaciones blancas o más claras que el fondo; vermiculaciones dorsales de grosor variable, fusionándose en algunos casos hasta formar manchas u ocelos.

English diagnosis: The holotype (Fig. 1) and two paratypes are mature females; two paratypes are males who just reached sexual maturity, with the claspers developed and slightly calcified; 17 paratypes were unborn (Fig. 2) and because of this condition, they were not considered in the diagnosis and in the description. Disc circular, their wide and their length are about equal; disc width 64.1-65.8\% of the total length (TL); disc length 64.1-65.8\% of TL; head length 54.3-57.6\% of TL; prepelvic length $50.5-52.4 \%$ of TL; distance from snout to anus $51.1-53.2 \%$ of TL; precaudal length $78.5-86.0 \%$ of TL; prespiracular length 14.1 $16.1 \%$ of TL; distance between the axils of the pelvics fins and the origin of the caudal fin $22.1-26.0 \%$ of TL; width between the axils of the pectorals fins $13.2-15.5 \%$ of TL; caudal ventral margin length $14.0-15.9 \%$ of TL; caudal dorsal margin length $7.5-8.9 \%$ of TL; 27 to 33 rows of teeth in the upper jaw; dorsal denticles or tubercles absent; back of the disc with a brown background with orange shades and white or pale vermiculations of variable thickness, sometimes merging to form spots or ocelli.

Descripción: La morfometría de los especímenes tipo se muestra en el cuadro 1, las medidas se expresan como porcentaje de la LT. Disco redondeado, su longitud es similar a su ancho, ambas medidas caben 1.5 a 1.6 veces en LT; margen anterolateral ligeramente convexo en hembras, mientras que en los machos el ángulo es mayor con ligera tendencia a la concavidad; la región del hocico es más roma en las hembras en tanto en los machos es más puntiaguda; la distancia preorbital cabe 6.6 a 8.5 veces en LT. La longitud de la punta del hocico a la inserción de las aletas pélvicas es 1.9 a 2.0 veces la LT. Las aletas pélvicas presentan una forma trapezoide y su base es de longitud similar a su borde anterior (0.9 a 1.1 veces); el borde anterior se origina a la altura del inicio de la cloaca y se extiende hasta alcanzar el extremo posterior del disco; el borde posterior sobresale de manera convexa del disco y alcanza el borde interno, el cual se fusiona en la parte ventral con la cola; ambos bordes son redondeados, principalmente en su ángulo distal; la longitud del borde posterior es 
mayor a la distancia que existe entre las axilas de las aletas pélvicas y guarda una relación de 7.1 a 8.2 veces la LT. Cola corta y robusta, su longitud es menor a la del disco (1.3 a 1.4 veces la primera en la segunda) y cabe 2.1 a 2.2 veces en LT; es de forma cilíndrica pero en su parte ventral está ligeramente aplanada (Fig. 3); su grosor y altura son máximos en la base del pedúnculo caudal, cercanos al eje de las axilas de las aletas pélvicas; la altura y ancho en este eje es de $9.3-10.4 \%$ y $12.5-14.7 \%$ la longitud de la cloaca al extremo de la caudal, respectivamente; el origen de la espina caudal es equidistante a la base del pedúnculo y al origen dorsal de la caudal, su extremo alcanza y en ocasiones sobrepasa el origen de la aleta caudal. La aleta caudal ligeramente robusta, ovalada; el lóbulo dorsal es más alto que el ventral pero su longitud es menor, su borde posterior es ovalado y cabe 10.1 a 11.8 veces en la longitud de la cola; la distancia de la punta del hocico al origen dorsal caudal es 78.5-86.1\% de LT; la distancia que hay entre la axila de las pélvicas y el inicio de la caudal con respecto a la LT es de 22.1-26.0\%. El diámetro orbital cabe 3.2 a 4.2 veces en la longitud del hocico y representa el 3.1-3.7\% de LT; longitud preoral mayor que la máxima longitud internasal (1.2-1.6 veces la segunda en la primera); interorbital ancho (6.9-8.3\% de LT), 2.0 a 2.4 veces el diámetro ocular. La longitud del espiráculo es 1.3 a 1.6 veces más grande que el ojo (representando un $3.9-5.0 \%$ de LT), y 0.5 a 0.7 veces el espacio interorbital (Fig. 4); su inserción inferior sobrepasa anteriormente la mitad de la longitud ocular; la distancia interespiracular representa el $9.2-9.7 \%$ de LT y en ella cabe el diámetro ocular 2.5-3.1 veces. La distancia prenasal cabe 6.7 a 7.6 veces en la longitud del disco; la cortina nasal se origina en el borde dorsal interno de la narina, lateralmente sus bordes alcanzan los pliegues labiales comisurales y en profundidad se extiende hasta alcanzar la de los pliegues labiales; los bordes laterales son rectos interrumpidos en su parte media por un plegamiento sinuoso; el borde horizontal presenta un pliegue continuo a manera de flecos cortos con bases anchas; la longitud del pliegue lateral representa el 35.0-48.4\% del horizontal (Fig. 5). Distancia entre las primeras aberturas branquiales 1.6 a 1.8 veces la distancia internasal externa; distancia entre las quintas aberturas branquiales 1.0 a 1.2 veces la distancia internasal externa. Tanto la región dorsal y ventral del disco así como la región caudal están desnudas, no presentan dentículos ni aguijones.

English description: Morphometric data of type specimens, expressed as percentages of TL, are given in Table 1. Disc rounded, its length similar to its width, both measures fit 1.5 to 1.6 times in TL; in females the anterolateral disc margin is slightly convex, in males the angle is greater with a slight tendency to concavity; in females the snout is blunt, in males is more pointed; preorbital distance 6.6 to 8.5 times in TL. The length from the tip of the snout to the insertion of the pelvic fins is 1.9 to 2.0 times in TL. The pelvic fins have a trapezoid shape and the length of its base is similar

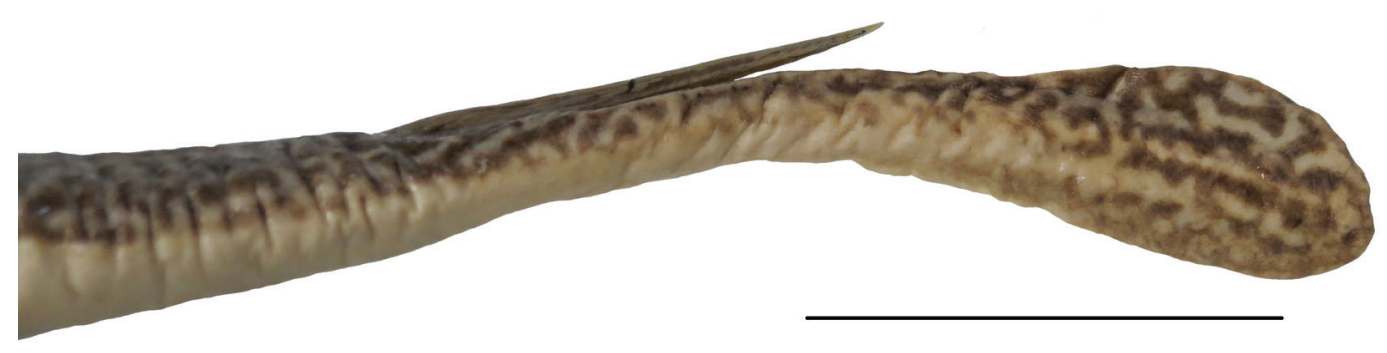

Fig. 3. Vista lateral de la parte posterior de la cola de Urobatis pardalis sp. nov., hembra adulta, Holotipo (UCR 2289-1, 462mm LT). Barra de escala 50mm.

Fig. 3. Urobatis pardalis sp. nov., caudal fins of holotype (UCR 2289-1) adult female (462mm TL). Scale bar 50mm. 


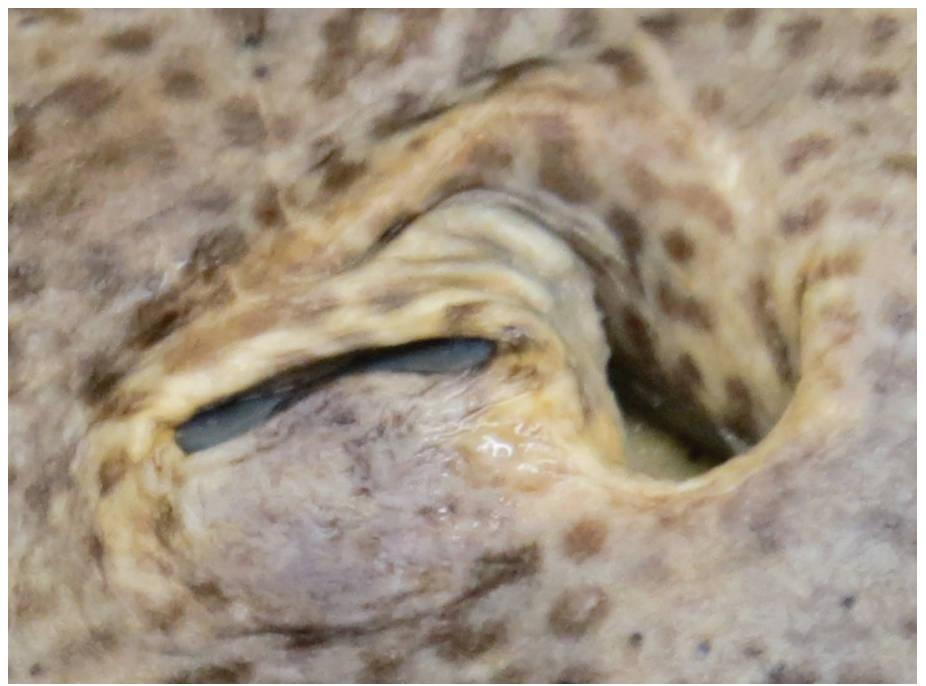

Fig. 4. Región orbito-espiracular de Urobatis pardalis sp. nov., hembra adulta, holotipo (UCR 2289-1, 462mm LT, preservada), muestra el tamaño relativo y posición del espiráculo y la órbita ocular.

Fig. 4. Orbito-spiracular region of Urobatis pardalis sp. nov., adult female holotype (UCR 2289-1, 462mm TL, preserved) showing the relative sizes and positions of the spiracle and orbit.

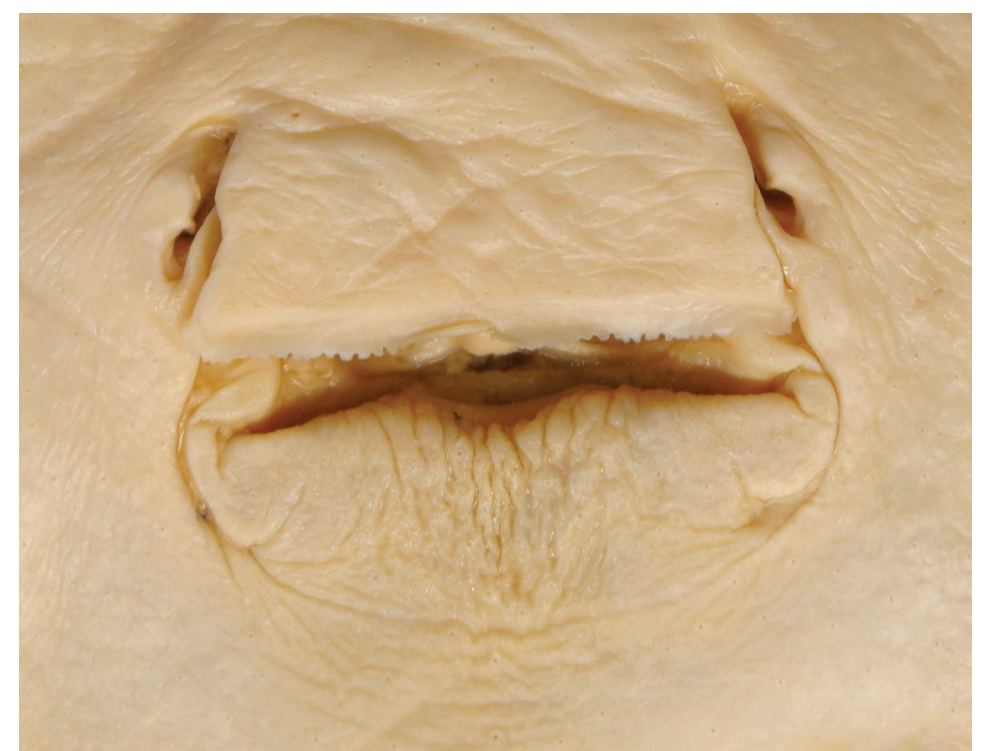

Fig. 5. Región oronasal de Urobatis pardalis sp. nov., hembra adulta, holotipo (UCR 2289-1, 462mm LT).

Fig. 5. Oronasal region of Urobatis pardalis sp. nov., adult female, holotype (UCR 2289-1, 462mm TL).

to the length of its anterior margin (0.9 to 1.1 times); the anterior margin originates at the origin of the cloaca and extends until reach the posterior end of the disc; the posterior margin protrude convexly from the disc and reaches its inner margin, which merges with the tail into the ventral part; both edges are rounded, mainly on its distal angle; the length of the posterior margin is greater than the distance between the axils of the pelvic fins, the posterior margin is 7.1 to 8.2 times in TL. Tail short and stout, its length is less than the disk length (1.3 to 1.4 
times the first in the second) and it is 2.1 to 2.2 times in TL; cylindrical in shape, with the ventral part slightly flattened (Fig. 3.); its thickness and its height are maximum at the base of the caudal peduncle, close to the axis of the axils of the pelvics fins; the height and width at this axis is $9.3-10.4 \%$ and $12.5-14.7 \%$ the length of the origin of the anus to the end of the caudal fin, respectively; the origin of the caudal spine is equidistant to the base of the caudal peduncle and to the caudal dorsal origin, its end reaches and sometimes exceeds the origin of the caudal fin. The caudal fin is slightly robust, oval in shape; the dorsal lobe is higher than the ventral but its length is shorter, its posterior margin is oval in shape and it is 10.1 to 11.8 times in the length of the tail; the distance from the tip of snout to the caudal dorsal origin is $78.5-86.1 \%$ of TL; the distance between the axils of the pelvic fins and the origin of the caudal fin is $22.1-26.0 \%$ of TL. The orbital diameter is 3.2 to 4.2 times in snout length, and represents $3.1-3.7 \%$ of TL; preoral length greater than the maximum internasal length (1.2-1.6 times the second on the first); the interorbital wide (6.9$8.3 \% \mathrm{TL}$ ) is 2.0 to 2.4 times the eye diameter. The spiracle length is 1.3 to 1.6 times larger than the eye (representing $3.9-5.0 \%$ of TL), and 0.5 to 0.7 times in the interorbital space (Fig 4.); its inferior insertion exceeds the half of the eye length; the interespiracular distance represents $9.2-9.7 \%$ of TL and it fits 2.5-3.1 times in the eye diameter. Prenasal distance 6.7 to 7.6 times in the length of the disc; nasal curtain originates at the inner dorsal edge of the nostril, laterally its borders reach the commissural folds and horizontally extends up to reach the labial folds; the lateral margins are straight, interrupted in their middle by a sinuous fold; the horizontal margin has a continuous fold with short and broad based fringes; lateral fold length $35.0-48.4 \%$ of the horizontal fold (Fig. 5). Distance between first gill openings 1.6 to 1.8 times the external internarial length; distance between fifth gill openings 1.0 to 1.2 times the external internarial length. Disc and tail naked, without denticles or thorns.
Coloración: Los ejemplares fijados y preservados presentan el siguiente patrón de coloración: la región ventral es de color blanco o crema, con tintes rosados; la región dorsal es de color pardo con tonos anaranjados, presentando vermiculaciones más claras que el fondo, sobre todo en el borde del disco; estas vermiculaciones varían en grosor y disposición, algunas son cortas y anchas a manera de manchas, otras forman círculos envolviendo al color del fondo dando la apariencia de ocelos; en ocasiones los ocelos y manchas presentan una disposición paralela al borde del disco. Ejemplares recién capturados o en estado libre (Fig. 6) presentan una coloración más marcada, incluso tienen la capacidad de intensificar o disminuir la coloración; es posible observar ejemplares que presentan en el dorso del disco círculos bien delimitados que se originan al intensificar la coloración del fondo.

Embriones: Los embriones al igual que los adultos presentan una piel desnuda, sin tubérculos ni aguijones recurvados; desde ese estadio, la espina caudal está presente, sin aserraciones marcadas, y sin estar completamente calcificada, presentando una consistencia blanda; la forma del disco es ovalada; es notable el proceso de encefalización por lo que el diámetro orbital es ligeramente mayor con respecto al espiráculo; en la parte dorsal ocular corre hacia la parte posterior una proyección que se extiende lateralmente de forma perpendicular a la órbita ocular, esta proyección es una reminiscencia del lóbulo espiracular embrionario que se transformará hasta desaparecer conforme el organismo crece; el diámetro vertical de la abertura espiracular es mayor que el ocular. La coloración es muy similar entre sexos: color de fondo pardo claro sobre el cual se presenta un distintivo patrón de círculos y semicírculos oscuros que se extienden del dorso hacía los bordes del disco; en cada círculo, hay uno o dos puntos distintivos en el centro; conforme se acercan a los bordes el diámetro de los círculos disminuye hasta que se pierde en una serie de reticulaciones o puntos que bordean de manera paralela el disco; la aleta caudal es oscura; las 


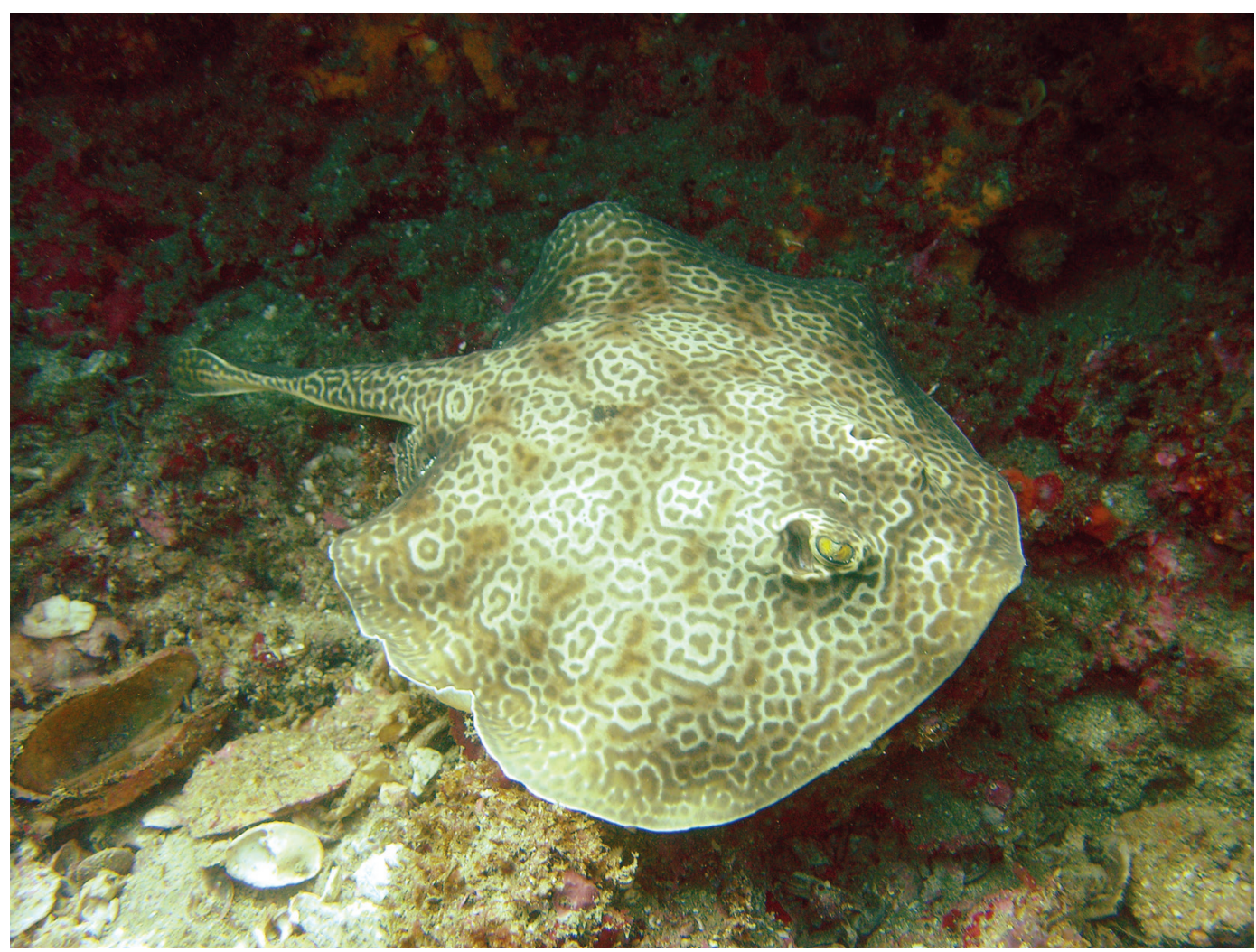

Fig. 6. Urobatis pardalis sp. nov. en Bajo Rojo, Bahía Salinas, Provincia de Guanacaste, Costa Rica (fotografía cortesía de Jorge Cortés, 22 de febrero de 2007).

Fig. 6. Urobatis pardalis sp. nov. in Bajo Rojo, Bahia Salinas, Province of Guanacaste, Costa Rica (photography courtesy of Jorge Cortés, February 22, 2007).

órbitas están bordeadas en la parte superior y anterior por una franja oscura.

Distribución: Esta especie se distribuye en el Pacífico oriental tropical, su límite sur son las costas de Colombia y al norte las costas de Costa Rica (v.gr., Allen, \& Robertson, 1998; Bussing, \& López, 2005, 2011; Mejía-Falla, \& Bolaños-Cubillos, 2011).

Etimología: El epíteto "pardalis", derivando de la antigua palabra griega que refiere al leopardo o pantera ("pardus" leopardo o pantera y "-alis" un sufijo adjetival que significa "igual" o "como"), fue asignado a esta nueva especie debido a que su patrón de coloración dorsal es muy similar a la del félido.
Material comparativo: 15 ejemplares. Urobatis concentricus: 1 ejemplar. CNPEIBUNAM 2167, 1 ejemplar, hembra, Playa Negritos, Bahía de Chamela, Jalisco, México. Urobatis halleri: 5 ejemplares. CNPE-IBUNAM 17506 (ex ITESM 90-23), 5 ejemplares, 3 hembras y 2 machos, frente a la Playa (y campo Pesquero) Santo Tomás, Guaymas, Sonora, México. Urobatis jamaicensis: 5 ejemplares. CNPE-IBUNAM 3137, 1 ejemplar, hembra, Celestún, Yucatán, México. CNPEIBUNAM 10689, 1 ejemplar, macho, Playa Bonita, Campeche, Campeche, México. CNPE-IBUANM 4639, 2 ejemplares, machos, Punta Estrella, La Escollera, Puerto Morelos, Quintana Roo, México. CNPE-IBUNAM 763, 1 ejemplar, hembra, Puerto Progreso, Yucatán, 
México. Urobatis maculatus: 4 ejemplares. CNPE-IBUNAM 17117 (ex ITESM 82-27A), 3 ejemplares, 1 hembra y 2 machos, frente a Playa Cochorit, ca. 1-4 millas a ESE de Cabo
Haro, Empalme, Guaymas, Sonora, México. CNPE-IBUNAM 16442 (ex ITESM 79-19), 1 ejemplar, macho, Los Bajos de La Reina, Bahía de Bacochibampo, Guaymas, Sonora, México.

\section{Clave dicotómica para la determinación taxonómica de las especies del género Urobatis}

1a. Dorso del disco y/o cola con una o más series de dentículos dérmicos, tubérculos y/o espinas evidentes (en ejemplares neonatos no están desarrollados y en juveniles no son muy evidentes) $\ldots \ldots \ldots \ldots \ldots \ldots \ldots \ldots \ldots \ldots \ldots \ldots 2$

1b. Dorso del disco desnudo, sin dentículos dérmicos, tubérculos o espinas evidentes $\ldots \ldots \ldots \ldots \ldots \ldots \ldots$

2a. Superficie dorsal del disco de color pardo amarillento, pardo claro, canela, verde oscuro o pardo oscuro con numerosas manchas o puntos de color pardo oscuro, verde, dorado o blanco, de tamaño variable, formando un patrón reticulado o vermiculado; superficie ventral de color pardo claro, crema o verduzco, con los bordes usualmente más oscuros; con

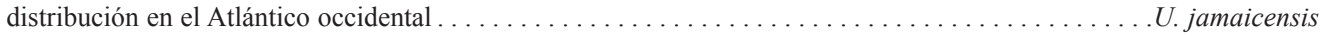

2b. Superficie dorsal del disco de color marrón con líneas onduladas oscuras y claras y manchas blancas del tamaño del ojo; superficie ventral de color pardo, pardo claro, blanco, rosa o crema, con los bordes usualmente más oscuros y un patrón reticulado de manchas pálidas sobre un fondo más oscuro en la parte posterior del disco y de las aletas pélvicas;

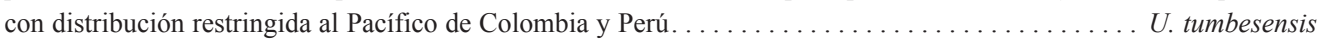

3a. Superficie dorsal del disco de color plomo jaspeado, con numerosas manchitas y/o vermiculaciones blancas; superficie ventral de color blanquecino uniforme, con los bordes usualmente más oscuros; con distribución restringida al Pacífico

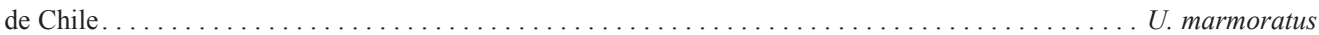

3b. Patrón de coloración no como el descrito anteriormente, con distribución restringida entre el Pacífico sur de Estados

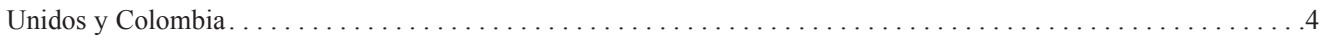

4a. Superficie dorsal del disco de color pardo o gris pardo, con manchas o puntos irregulares (asimétricos) pardo oscuros o negros, y de tamaño variable, relativamente espaciados; 35 a 37 hileras de dientes en la mandíbula superior; endémica

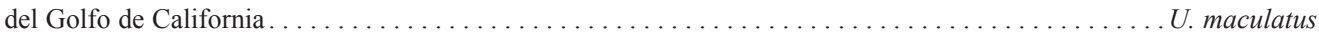

4b. Patrón de coloración dorsal del disco con un fondo de color gris claro, verde olivo a pardo claro y uniforme, cubierto con líneas, parches, puntos pequeños o vermiculaciones, nunca con manchas o puntos negros u oscuros irregulares; 26

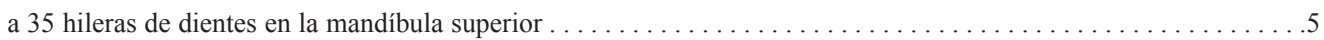

5a. Superficie dorsal del disco de color gris claro con líneas, parches y pequeños puntos oscuros, estos últimos, más o menos ordenados en filas concéntricas; 2 franjas pálidas, estrechas, cerca de los bordes del disco; con distribución

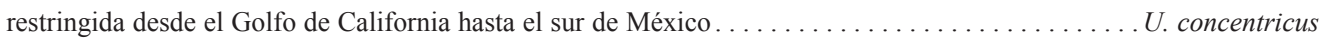

5b. Superficie dorsal del disco de color uniforme o con vermiculaciones, puntos o manchas más claras que el fondo, mismas que varían en su grosor y disposición; sin franjas claras cerca de los bordes del disco; con distribución restringida

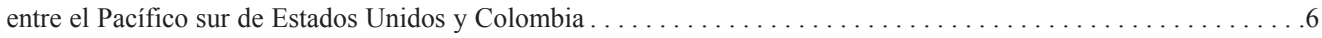

6a. Superficie dorsal del disco de color pardo claro, verde olivo, o canela uniforme, o pardo con vermiculaciones más claras que el fondo, mismas que varían en su grosor y disposición; longitud del disco 54-58\% de LT; ancho del disco 56-60\% de LT; con distribución restringida entre el Pacífico sur de Estados Unidos y el sur de México . . . U. halleri

6b. Superficie dorsal del disco de color pardo o gris pardo, con manchas o puntos irregulares pardo oscuros o negros, de tamaño variable, relativamente espaciados; longitud del disco 64-66\% de LT; ancho del disco 62-65\% de LT; con distribución restringida entre el Pacífico norte de Costa Rica y Colombia ................. pardalis sp. nov.

\section{DISCUSIÓN}

Urobatis pardalis sp. nov. difiere de sus congéneres por el patrón de coloración dorsal del disco. La especie U. maculatus presenta un color pardo o gris oscuro como fondo con manchas negras circulares o elipsoidales bordeadas por una banda más tenue, y se diferencia de $U$. pardalis sp. nov., que nunca presenta vermiculaciones o reticulaciones (Allen, \& Robertson, 1994; McEachran, 1995). La especie $U$. concentricus presenta el mismo color en el dorso del disco que $U$. maculatus pero sin manchas negras, en su lugar, presenta 
un patrón de manchas a manera de círculos u óvalos, de color blanquecino, dispuestas en la región central del disco y de manera simétrica a los costados (Allen, \& Robertson, 1994; McEachran, 1995), difiere también de U. pardalis sp. nov. al no presentar vermiculaciones ni manchas como se disponen en esta última. Urobatis concentricus presenta además dos bandas claras equidistantes en los bordes del disco, ausentes en $U$. pardalis sp. nov. (Allen, \& Robertson, 1994; McEachran, 1995). La especie $U$. tumbesencis presenta un fondo de color verdoso a pardo y está cubierto con manchas blancas que tienen una disposición a manera de rosetas (Mejía-Falla, \& BolañosCubillo, 2011), difiere también de $U$. pardalis sp. nov. al no presentar vermiculaciones ni manchas como se disponen en esta última. De acuerdo a la descripción que hace Philippi (1892) de U. maculatus, la coloración de esta especie consiste en un fondo de color plomo jaspeado con numerosas manchas pequeñas (Lamilla, \& Bustamante, 2005); es muy poco lo que se conoce de esta especie, incluso se desconoce el paradero del holotipo (Eschmeyer, 2014). Por último, las especies U. jamaicensis y $U$. halleri presentan una amplia variación en la coloración dorsal del disco (Babel, 1967), sin embargo en ambas es predominante el patrón de manchas pequeñas con diámetro menor al de la órbita ocular (McEachran, \& de Carvalho, 2003; Mejía-Falla, \& Bolaños-Cubillo, 2011); cuando son predominantes las reticulaciones estas no son tan marcadas en todo el disco como en el caso de $U$. pardalis sp. nov.

Los caracteres morfométricos también permiten distinguir a $U$. pardalis sp. nov. del resto de las especies dentro del género. En esta última, el ancho del disco (62-65\% de LT) y su longitud (64-66\% de LT) son mayores con respecto a la longitud total, sus congéneres tienen una relación menor: en $U$. jamaicensis el ancho del disco es $50-54 \%$ y la longitud es $55-60 \%$; en $U$. concentricus el ancho es $59-60 \%$ y la longitud del disco es 59-60\%; en $U$. halleri el ancho es $56-60 \%$ y la longitud es $54-58 \%$; y en $U$. maculatus el ancho es $57-61 \%$ y la longitud es $57-61 \%$. Además la longitud cefálica
(54-58\% de LT), la prepélvica (50-52\% de LT) y la preanal (51-53\% de LT) son mayores en $U$. pardalis sp. nov. en comparación con el resto de las especies del género: en $U$. jamaicensis la longitud cefálica representa el $47-52 \%$ de LT, la prepélvica $45-50 \%$ de LT y la preanal $46-51 \%$ de LT; en $U$. concentricus la longitud cefálica es $52-53 \%$ de LT, la prepélvica $48-49 \%$ de LT y la preanal $49-50 \%$ de LT; en $U$. halleri la longitud cefálica es $47-52 \%$ de LT, la prepélvica $44-48 \%$ de LT y la preanal $47-51 \%$ de LT; en $U$. maculatus la longitud cefálica es $50-54 \%$ de LT, la prepélvica $46-49 \%$ de LT y la preanal $48-52 \%$ de LT. Por su parte, la longitud precaudal $(78-86 \%$ LT) y la del margen ventral caudal (14-16\% LT) son proporcionalmente más cortas en $U$. pardalis sp. nov. que entre sus congéneres: en $U$. jamaicensis la longitud precaudal es $86-92 \%$ de LT y el margen ventral caudal es $19-22 \%$ LT; en $U$. concentricus, la longitud precaudal es $88-89 \%$ LT y el margen ventral caudal es $17-18 \%$ LT; en $U$. halleri la longitud precaudal es $85-88 \%$ LT y el margen ventral caudal es $20-24 \%$ LT; y en $U$. maculatus la longitud precaudal es $78-86 \%$ LT y el margen ventral caudal es $19-24 \%$ LT. Urobatis pardalis sp. nov. presenta también mayores longitudes prespiraculares (14-16\% LT vs $13-15 \%$ LT) y aquella de la axila de la aletas pélvicas al inicio de la aleta caudal (22-26\% LT vs $19-24 \%$ LT) y menores en cuanto al ancho entre las axilas de las aletas pectorales (13-16\% LT vs $14-18 \%$ LT) y la longitud dorsal de la aleta caudal (7-9\% LT vs $12-15 \%$ LT) en comparación con U. halleri.

Con base en ciertas características anatómicas es posible además distinguir a la nueva especie del resto de sus congéneres. Así se distingue a $U$. pardalis sp. nov. de $U$. jamaicensis y U. tumbesencis por la ausencia de dentículos o tubérculos dérmicos en la superficie dorsal del disco; y de U. maculatus por el número de hileras de dientes en la mandíbula superior (35 a 37 vs 27 a 33 en $U$. pardalis sp. nov.). También puede distinguirse esta nueva especie de las otras especies de la familia Urotrygonidae por la forma de la pupila (Fig. 7) (López 


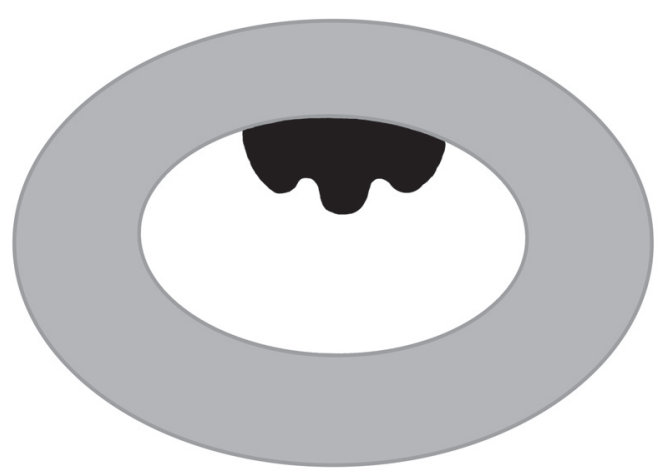

Fig. 7. Esquema de la configuración de la pupila de Urobatis pardalis sp. nov.

Fig. 7. Schematic configuration of the pupil of Urobatis pardalis sp. nov.

\& Bussing, 1998; Rubio-Rodríguez, NavarroGonzález, \& Vergara-Solana, 2010).

Por último, la distribución geográfica de las especies del género Urobatis presenta patrones definidos y pueden ayudar también a discriminar entre especies. La especie $U$. jamaicensis, es endémica del Atlántico occidental (McEachran, \& Fechhelm, 1998; Cervigón-Marcos, \& Ramírez-Nahim, 2012), mientras que el resto lo son para el Pacífico oriental (Allen, \& Robertson, 1994). Así U. halleri se ha registrado desde las costas de Oregón, Estados Unidos (Miller, \& Lea, 1972), hasta el sur de México, siendo la especie más septentrional. En contraparte, U. marmoratus es la más meridional, y aparentemente se encuentra restringida a las costas de Chile, donde las aguas son frías (De Buen, 1959; Eschmeyer, 2014). U. maculatus está ampliamente distribuida en las costas del Golfo de California donde es endémica (Castro-Aguirre, \& Espinosa-Pérez, 1996); de manera similar $U$. concentricus era considerada como endémica del mismo mar, sin embargo recientemente ha sido registrado en la costa central del Pacífico mexicano (MárquezEspinosa, 2012). Las costas de Perú, al sur, y Colombia al norte, constituyen los límites de distribución de $U$. tumbesensis (Chirichigno, \& McEachran, 1979), mientras que Urobatis pardalis sp. nov., es representante de la región biogeográfica Panámica (sensu Briggs, 1974), encontrándose desde la costa pacífica de Costa Rica hasta Colombia.

\section{AGRADECIMIENTOS}

Los autores dedican este estudio a la memoria del Dr. William Bussing (q.e.p.d.), fallecido en noviembre de 2014, quien contribuyo sustancialmente al desarrollo de la Ictiología en Costa Rica. Además agradecen a Ana Rosa Ramírez y Carolina Méndez por las facilidades brindadas durante la estancia en el Museo de Zoología de la UCR, así también a Héctor Espinosa Pérez por el acceso al material comparativo alojado en la CNPE-IBUNAM. El primer autor agradece al CONACyT por la beca otorgada para poder realizar sus estudios de posgrado, así mismo al Posgrado en Ciencias Biológicas de la UNAM.

\section{RESUMEN}

Nueva especie del género Urobatis (Myliobatiformes: Urotrygonidae) del Pacífico oriental tropical. Una nueva especie de raya redonda con espina, Urobatis pardalis sp. nov., es descrita a partir de material recolectado en las costas del Pacífico de Costa Rica. Esta nueva especie difiere de sus congéneres por el patrón de la coloración dorsal del disco y por varias relaciones de medidas. Se presenta una clave para la determinación taxonómica de las especies del género.

Palabras clave: nueva especie, Urobatis pardalis sp. nov., raya redonda, Costa Rica, Centroamérica.

\section{REFERENCIAS}

Aguilera, O. (1998). Los peces marinos del occidente de Venezuela. Acta Biológica Venezuelica, 18, 43-57.

Allen, G. R., \& Robertson, D. R. (1994). Fishes of the Tropical Eastern Pacific. Hawaii, Honolulú: University of Hawaii.

Allen, G. R., \& Robertson, D. R. (1998). Peces del Pacifico Oriental tropical. México D.F: Comisión Nacional para el Conocimiento y Uso de la Biodiversidad, CEMEX, S.A. y Agrupación Sierra Madre, S.C.

Babel, J. S. (1967). Reproduction, life history, and ecology of the round stingray, Urolophus halleri Cooper. California Department of Fish and Game, Fish Bulletin, 137, 1-104. 
Beebe, W., \& Tee-Van, J. (1941). Fishes from the tropical eastern Pacific (from Cedros Island, Baja California, south to the Galapagos Islands and northern Peru). Rays, mantas and chimaeras. Zoologica, 26, 245-280.

Bigelow, H. B., \& Schroeder, W. C. (1953). Saw fishes, guitar fishes, skates, rays, and chimaeroids. In J. TeeVan, C. M. Breder, A. E. Parr, W. C. Schroeder, \& L. P. Schultz (Eds.), Fishes of the Western North Atlantic (pp. 1-514). Part 2. Memoir Sears Foundation for Marine Research.

Böhlke, J. E., \& Chaplin, C. C. G. (1968). Fishes of the Bahamas and adjacent tropical waters. United States of America: University of Texas Press.

Briggs, J. C. (1974). Marine zoogeography. New York: McGraw-Hill Book Company.

Bussing, W. A., \& López, M. I. (2005). Peces de la Isla del Coco y peces arrecifales de la costa pacífica de América Central meridional. Revista de Biología Tropical, 53(2), 1-192.

Bussing, W. A., \& López, M. I. (2009). Marine Fish. In I. S. Wehrtmann, \& J. Cortés (Eds.). Marine biodiversity of Costa Rica, Central America (pp. 453-458). Berlin: Springer Science \& Business Media.

Bussing, W. A., \& López, M. I. (2011). Peces demersales y pelágicos costeros del Pacífico de Centroamérica meridional. San José: Editorial de la Universidad de Costa Rica.

Cappetta, H. (1987). Chondrichthyes II. Mesozoic and cenozoic Elasmobranchii. In H. P. Schultze (Ed.), Handbook of Paleoichthyology (pp. 1-193). Stuttgart: Gustav Fischer.

Castro-Aguirre, J. L., \& Espinosa-Pérez, H. (1996). Listados Faunísticos de México VII. Catálogo sistemático de las rayas y especies afines de México (Chondrichthyes: Elasmobranchii: Rajiformes: Batoideioorpha). México, D.F: Instituto de Biología, UNAM.

Cervigón-Marcos, F., \& Ramíez-Nahim, H. (2012). Peces marinos de las costas de Venezuela. Venezuela, Caracas: Fundación Museo Del Mar.

Chirichigno, F. (1974). Clave para identificar los peces marinos del Perú. Instituto del Mar del Perú, 44, $1-390$.

Chirichigno F., N., \& McEachran, J. D. (1979). Urolophus tumbesensis, a new stingray from the coast of Peru (Batoidea: Urolophidae). Copeia, 1979, 709-713.

Compagno, L. J. V. (1999). Checklist of living elasmobranches. In W. C. Hamlett (Ed.), Sharks, skates, and rays. The biology of elasmobranch fishes (pp. 471-498). Baltimore: The John Hopkins Univ. Press.

Compagno, L. J. V. (2005). Checklist of living Chondrichthyes. In W. C. Hamlett (Ed.), Reproductive Biology and Phylogeny of Chondrichthyes: sharks, batoids, and chimaeras (pp. 501-548). New Hampshire, United States of America: CRC Press.

Cooper, J. G. (1863). On new genera and species of Californian fishes-No. II. Proceedings of the California Academy of Sciences (Series 1), 3, 93-97.

Cuvier, G. (1816). Le Règne Animal distribué d'après son organisation pour servir de base à l'histoire naturelle des animaux et d'introduction à l'anatomie comparée. Les reptiles, les poissons, les mollusques et les annélides (Edition 1, Vol. 2, pp. 1-532). Paris.

De Buen, F. (1959). Lampreas, tiburones, rayas y peces en la estación de Biología Marina de Montemar, Chile (Primera contribución). Revista de Biología Marina, Valparaíso, 9, 1-200.

Eschmeyer, W. N. (2014). Catalog of fishes: genera, species, references [On tine forum comment]. Retrieve from $\mathrm{http} / / /$ research.calacademy.org/research/ichthyology/catalog/fishcatmain.asp.

Froese, R., \& Pauly, D. (2014). FishBase World Wide Web electronic publication (Version 06/2014) [FishBase Data]. Stockholm, Sweden: FishBase consortium. Retrieve from http://www.fishbase.org/search.php.

Garman, S. (1885). Notes and descriptions taken from selachians in the U. S. National Museum. Proceedings of the United States National Museum, 8, 39-44.

Garman, S. (1913). The Plagiostomia (sharks, skates, and rays). Memoirs of the Museum of Comparative Zoo$\log y, 36,1-515$.

Jordan, D. S. (1895). The fishes of Sinaloa. Proceedings of the California Academy of Sciences (Series 2), 5 , 377-514.

Lamilla, J., \& Bustamante, C. (2005). Guía para el reconocimiento de: tiburones, rayas y quimeras de Chile. Oceana, 17, 1-80.

Lamilla, J., \& Sáez, S. (2003). Clave taxonómica para el reconocimiento de especies de rayas chilenas. Investigaciones Marinas, Valparaiso, 31, 3-16.

Last, P. R., \& Compagno, L. J. V. (1999). Urolophidae. In K. E. Carpenter, \& V. H. Niem (Eds.), Species identification guide for fisheries purposes. The living marine resources of the western central Pacific. Batoid fishes, chimaeras and bony fishes part 1 (Elopidae to Linophrynidae) (pp. 1397-2068). Rome: FAO.

Last, P. R., \& Stevens, J. D. (1994). Sharks and Rays of Australia. Australia: CSIRO.

López, M. I., \& Bussing, W. A. (1998). Urotrygon cimar, a new eastern Pacific stringray (Pisces: Urolophidae). Revista de Biología Tropical, 46, 271-277.

Márquez-Espinosa, A. F. (2012). Guía de los peces marinos de la costa norte de Guerrero, México. México: Facultad de Estudios Superiores Iztacala, UNAM.

McEachran, J. D. (1995). Urolophidae. Rayas redondas. In W. Fischer, F. Krupp, W. Schneider, C. Sommer, 
K. E. Carpenter \& V. Niem (Eds.), Guía FAO para Identificación de Especies para los Fines de la Pesca. Pacifico Centro-Oriental (pp. 786-792). Rome: FAO.

McEachran, J. D., \& de Carvalho, M. R. (2003). Urolophidae. In K. E. Carpenter (Ed.), The living marine resources of the Western Central Atlantic. Volume 1. Introduction, molluscs, crustaceans, hagfishes, sharks, baroid fishes, and chimaeras. FAO species identification guide for fishery purposes and American Society of Ichthyologist and Herpetologists Special Publication No. 5 (pp. 572-574). Rome: FAO.

McEachran, J. D., \& Fechhelm, J. D. (1998). Fishes of the Gulf of Mexico, Vol. 1: Myxiniformes to Gasterosteiformes. Austin, Texas: University of Texas Press.

McEachran, J. D., Dunn, K. A., \& Miyake, T. (1996). Interrelationships of the batoid fishes (Chondrichthyes: Batoidea). In M. L. J. Stiassny, L. R. Parenti, \& G. D. Johnson (Eds.), Interrelationships of Fishes (pp. 63-84). New York: Academic Press.

Mejía-Falla, P. A., \& Navia, A. F. (2009). New records of Urobatis tumbesensis (Chirichigno \& McEachran, 1979 ) in the Tropical Eastern Pacific. Pan-American Journal of Aquatic Sciences, 4(3), 255-258.

Mejía-Falla, P. A., \& Bolaños-Cubillos, N. (2011). Familia Urotrygonidae. In P. A. Mejía-Falla, A. F. Navia, V. Puentes (Eds.), Guía para la identificación de especies de tiburones, rayas y quimeras de Colombia (pp. 243-259), Bogotá, Colombia: Ministerio de Ambiente y Desarrollo Sostenible; Corporación para el Desarrollo Sostenible del Archipiélago de San Andrés, Providencia y Santa Catalina - CORALINA; Gobernación de San Andrés, Providencia y Santa Catalina, Fundación SQUALUS.

Miller, D. J., \& Lea, R. N. (1972). Guide to the coastal marine fishes of California. Fish Bulletin, 157, 1-249.

Miyake, T., \& McEachran, J. D. (1988). Three new species of the stingray genus Urotrygon (Myliobatiformes:
Urolophidae) from the eastern Pacific. Bulletin of Marine Science, 42(3), 366-375.

Nelson, J. S. (1994). Fishes of the world. New York: John Wiley and Sons, Inc.

Nelson, J. S. (2006). Fishes of the world. Hoboken, New Jersey: John Wiley \& Sons.

Nelson, J. S., Crossman E. J., Espinosa-Pérez, H., Findley, L. T., Gilbert, C. R., Lea, R. N., \& Williams, J. D. (2004). Common and scientific names of fishes from the United States, Canada, and Mexico. Bethesda, Maryland: American Fisheries Society.

Osburn, R. C., \& Nichols, J. T. (1916). Shore fishes collected by the "Albatross" expedition in Lower California, with descriptions of new species. Bulletin of the American Museum of Natural History, 35, 139-181.

Philippi, R. A. (1892). Algunos peces de Chile. Las rayas, Callorrhynchus i Orthagoriscus Chilenos. Anales del Museo Nacional de Chile. Primera seccion, Zoologia, 3, 1-16.

Pollerspöck, J. (2014). Shark-References. Retrieve from www.shark-references.com

Robertson, D. R., \& Allen, G. R. (2008). Peces Costeros del Pacífico Oriental Tropical: Sistema de Información en línea (Versión 1.0.4.53). Retrieve from ww.http://biogeodb.stri.si.edu

Rubio-Rodríguez, U., Navarro-González, J. A., \& VergaraSolana, F. J. (2010). First record of black mucus and ocular malformations in the round stingray Urobatis halleri (Rajiformes: Urotrygonidae) at the southern Gulf of California, Mexico. Marine Biodiversity Records, 3:e17. doi:10.1017/S1755267209990960.

Yearsley, G. K., Last, P. R., \& Gomon, M. F. (2008). Trygonoptera imitata sp. nov., a new stingaree (Myliobatoidei: Urolophidae) from southeastern Australia. In P. R. Last, W. T. White, \& J. J. Pogonoski. Descriptions of new Australian Chondrichthyans (pp. 261-267). Retrieve from http://bionames.org/bionames-archive/ issn/1833-2331/22/261.pdf. 